\title{
Performance evaluation of a coupled method for the estimation of daily global solar radiation on a horizontal surface
}

\author{
Selmin ENER RUŞEN \\ Department of Energy Systems Engineering, Faculty of Engineering, Karamanoglu Mehmetbey University, 70100, \\ Karaman, Turkey; Academic Energy Research Group (AKEN), Faculty of Engineering, Karamanoglu Mehmetbey \\ University, 70100, Karaman, Turkey \\ E-mail: selmin.enerrusen@gmail.com
}

Received: May 29, 2017; accepted: August 2, 2018

\section{RESUMEN}

El cálculo exacto de la cantidad de radiación solar global potencial en la superficie de la tierra es uno de los parámetros más importantes para las inversiones en energía solar y los estudios de largo plazo sobre cambio climático. Por lo general, los datos más exactos de radiación solar están disponibles en estaciones terrestres que realizan mediciones directas. No obstante, en áreas donde esta información no es asequible, la radiación solar global puede estimarse utilizando algunos métodos de cálculo. En este estudio se comparan y analizan algunos métodos para estimar la radiación solar global que llega a una superficie horizontal, con el fin de establecer cuál es el más exacto. Las comparaciones se llevan a cabo entre algunos métodos empíricos convencionales obtenidos de la literatura, el método HELIOSAT basado en satélites y el método acoplado (híbrido) que emplea tanto datos de superficie como imágenes satelitales. Estos métodos se han probado antes y diversos investigadores han demostrado que son los más exactos para Turquía. Los resultados obtenidos sobre el desempeño se compararon con mediciones de superficie y todos los métodos se analizaron por medio de errores estadísticos en el sitio elegido. De acuerdo con los resultados de los últimos seis años de datos, el método acoplado (excepto en el caso del método Angstrom) es mejor que los otros, con valores diferenciales diarios $(91 \%)$ y valores diferenciales diarios absolutos de menos de $2.5 \mathrm{MJ} \mathrm{m}^{-2}$ por día.

\begin{abstract}
The accurate estimation of the amount of global solar radiation potential on the earth's surface is one of the most important parameters for solar energy investments and long-term climate studies. The most accurate solar radiation data are generally available in some ground stations where they are obtained by using direct measurement. However, the estimation of global solar radiation data can be conducted by some estimation methods in the areas that do not have this information. This study compares and discusses some approaches to identify the most accurate method for daily global solar radiation reaching on a horizontal surface. The comparisons are carried out between some selected conventional empirical methods taken from the related literature, the satellite-based HELIOSAT method and the coupled (hybrid) method which uses both ground data and satellite images. These selected methods have been tested previously and declared most accurate by many researchers for Turkey. The performance results were compared with ground-measured data and all methods were analyzed by using statistical errors in the selected site. According to the last six years of data results, the coupled method is better than the others (except the Angstrom method), with daily difference values $(91 \%)$ and daily absolute difference values lower than $2.5 \mathrm{MJ} \mathrm{m}^{-2}$ day.
\end{abstract}

Keywords: Solar radiation estimation, coupled method, satellite image, HELIOSAT. 


\section{Introduction}

With the development of technology, the use of electrical power increases day by day all over the world. It is foreseen that this power demand will be met by renewable energy sources in the future. Also, environmental impacts like global warming, climate change and an increase in carbon emissions to the atmosphere show the need of using clean and renewable power sources in the future. Solar energy, which has the highest power potential among all sources, has drawn the attention of technology developers (Myers, 2003; Ulgen and Hepbasli, 2009; Badescu et al., 2013; El Mghouchi et al., 2016). The accurate knowledge of solar radiation is of utmost importance in terms of planning the energy systems to be established, cost calculations and productivity analysis. Also, by investigating the changes in solar radiation that reach the Earth during a long period of time, its effects on climate change can be determined.

It is known that sunshine duration and radiation level can be directly measured from the ground by using typical meteorology stations equipped with solar radiation measurement devices. However, due to the high cost, maintenance and calibration requirements of solar radiation stations, ground measurements are not carried out in many places. Where solar radiation ground data are not available, many empiric estimation methods have been developed by creating suitable correlations to determine these data (Ulgen and Hepbasli, 2002; Yilmaz, 2010; Aktag and Yilmaz, 2012; Ener Ruşen et al., 2013; Gana and Akpootu, 2013; Kandirmaz et al., 2014; Teke et al., 2015). Regarding this matter, studies have been conducted by many researchers and empiric formulas related to different parameters were obtained (Tasdemiroglu and Sever, 1991; Ulgen and Hepbasli, 2002; Teke et al., 2015).

In recent years, satellite-based estimation methods have been commonly used for the estimation of solar radiation. Satellites cover large areas and facilitate data access or storage, which enable an extended use of satellite-based solar radiation estimation methods. The most popular satellite-based method is HELIOSAT-1, in which the cloud index and the clear-sky index are calculated by using the reflection data obtained from satellite images (Cano et al., 1986; Beyer et al., 1996; Pérez et al., 1997; Dagestad, 2005; Lu et al., 2011; Ener Ruşen et al., 2013; Alonso-Montesinos et al., 2015; Ener Ruşen, 2018).
Another estimation method is the coupled (hybrid) method, which is a combination of both ground and satellite data. In this method, the cloud index derived from satellite images and daily ground measurements during bright sunshine hours are taken into account to estimate the daily global solar radiation (Ener Ruşen et al., 2013; Kandirmaz et al., 2014; Ener Ruşen, 2015).

The aim of this study is to compare the performance of different methods for estimating global solar radiation in a selected city in the central Anatolia region of Turkey. This region is seen as the most efficient area where solar energy systems will be located. This region has also been designated as an energy-specialized industrial zone (ESIZ) in Turkey. Therefore, in this study, the Nevşehir area (one of the cities in central Anatolia) has been especially selected for the analysis of global solar radiation and to comparing the performance evaluations of different methods to estimate global solar radiation. For this purpose, six different estimation methods were selected among the models that have given successful results for Turkey. A 6-yr data set of the Nevşehir station in Turkey was used for the evaluations. In addition, the accuracy of the selected methods was tested by using statistical errors such as relative mean bias error (RMBE), relative root mean square error (RRMSE) and cumulative frequency. In the comparison of these methods, daily global solar radiation data from the ground observation station were used.

The next section provides information on the data set used in the present work. Section 3 summarizes the different methods: conventional, Angstrom-Prescott, Akinoglu and Ecevit's, Ulgen and Hepbasli's, HELIOSAT-1, and also explains briefly the coupled methods. The description of the statistical errors used in the present work is given in detail in section 4 . Section 5 presents and discusses the results and section 6 gives a conclusion together with a future research prospect.

\section{Available data}

The ground database was obtained from the Turkish State Meteorological Service (TSMS) for selected years in Turkey. This data set consisted of daily measurements of global solar radiation on a horizontal surface with a pyranometer; the duration of 
daily bright sunshine was either collected with a modern sunshine duration sensor, which makes use of photo-diodes (special design electronic systems), or with the classic Campbell-Stokes type sunshine recorder, which is widely used because it is simply operated. Many stations all over the world use this type of sunshine duration recorder, therefore longterm reliable sunshine duration data for at least 100 years are thought to be found all over the world (Myers, 2003; Muneer, 2004; Massen, 2011). The quality of all surface data sets was verified by the TSMS. Solar radiation data were available in instantaneous ground records for the selected location, and could be converted to hourly, daily or monthly global solar radiation values. The measuring instruments were mainly black and white-type thermopile pyranometers and new pyrheliometers. The data analyzed cover a 6 -yr period. It is adjusted to a useable form with the unit $\mathrm{MJ} \mathrm{m}^{-2}$ day $^{-1}$. The selected station (Nevşehir, Turkey) is located at $38.37^{\circ} \mathrm{N}$, $34.42^{\circ} \mathrm{E}, 1259.54$ masl. The geographical location of the selected station and a schematic representation of satellite observations are given in Figure 1. The climate regime of Nevşehir was defined as cold steppe climate or cold semi-arid (BSk) according to the Köppen-Geiger climate classification (Threwartha and Lyle, 1968). In addition, satellite images from the last 6 yrs were taken from the METEOSAT-8 satellite. With these data, hourly global solar radiation and cloud index values for the selected station were calculated by using the HELIOSAT

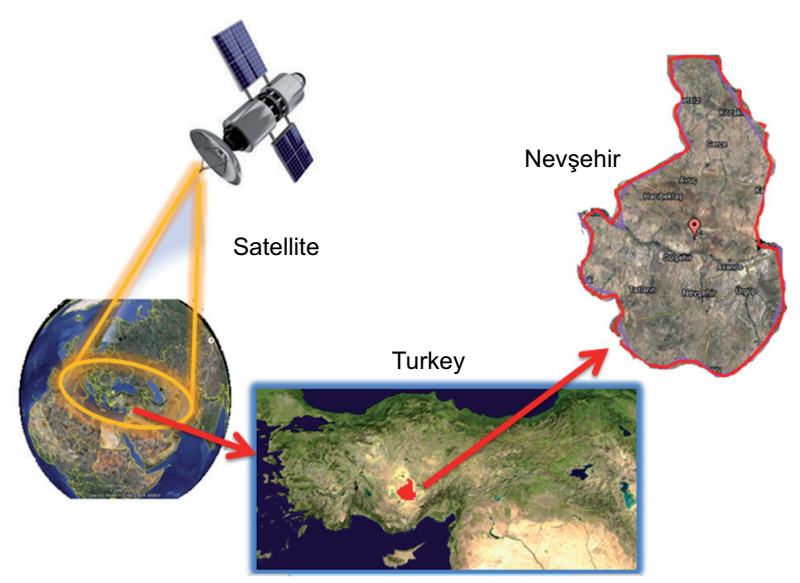

Fig. 1. Schematic representation of satellite observations and geographical location of the selected station in Turkey. method. From these data, the daily summation of global solar radiation was derived. The HELIOSAT-1 calculation procedure and satellite visible channel images were obtained from the University of Oldenburg.

\section{Conventional methods}

\subsection{Angstrom-Prescott $\left(H_{1}\right)$ method}

This method is commonly used to estimate daily or monthly mean global solar radiation. There is an empirical correlation between daily sunshine hours and daily global solar radiation:

$\frac{H_{1}}{H_{0}}=a+b \frac{s}{S_{0}}$

where $H_{1}$ is the daily global solar radiation and $H_{0}$ the daily extraterrestrial solar radiation on a horizontal surface; $s$ and $S_{0}$ are the daily bright sunshine hours and the day length, respectively, and $a$ and $b$ are regression coefficients. The values of these coefficients are estimated by using monthly averages of measured daily global solar radiation together with the monthly average of bright sunshine hour values. The empirical values $a$ and $b$ are called Angstrom coefficients and are site-dependent. Hence, correlations exist in many locations all over the world and are utilized extensively. However, the regression obtained for one location should not be used for sites having different climates and/or located far from the location where the correlation is obtained. The regression coefficients were estimated using monthly local measurement datasets of Nevşehir. The calculation procedures for this method are given by Duffie and Beckmann (1991).

Daily extraterrestrial solar radiation on a horizontal plane $\left(H_{0}\right)$ can be found as a function of solar constant $\left(G_{\mathrm{sc}}=1367 \mathrm{~W} \mathrm{~m}^{-2}\right)$, solar correction factor of the earth $(f)$, declination angle $(\delta)$, latitude of the area $(\phi)$, and solar hour angle $\left(\omega_{\mathrm{s}}\right)$ (Duffie and Beckman, 1991).

$$
\begin{aligned}
& H_{0}=\left(\frac{24}{\pi}\right) \cdot G_{S C} \cdot f \cdot {\left[\cos \phi \cdot \cos \delta \cdot \sin \omega_{S}\right.} \\
&\left.+\left(\frac{\pi}{180}\right) \cdot \omega_{S} \cdot \sin \phi \cdot \sin \delta\right]
\end{aligned}
$$

The daytime length in hours $\left(S_{0}\right)$ changes depending on the hour angle $\left(\omega_{\mathrm{s}}\right)$ according to the different time periods of the year (Duffie and Beckman, 1991). 
$S_{0}=\left(\frac{2}{15}\right) \cdot \omega_{S}=\left(\frac{2}{15}\right) \cdot \arccos (-\tan \delta \cdot \tan \phi)$

\subsection{Akinoglu and Ecevit's method $\left(\mathrm{H}_{2}\right)$}

Akinoglu and Ecevit (1990) used the changes of $a$ and $b$ values from a hundred different stations around the earth for the purpose of obtaining a quadratic form of Angstrom equation. The original Angstrom linear equation is given by the following quadratic equation:

$\frac{H_{2}}{H_{0}}=\left[0.145+0.845\left(\frac{s}{S_{0}}\right)-0.280\left(\frac{s}{S_{0}}\right)^{2}\right]$

\subsection{Ulgen and Hepbasli's Method $\left(\mathrm{H}_{3}\right)$}

By using 19 years of data from Ankara, Istanbul, and Izmir provinces, Ulgen and Hepbasli (2002) developed the following equation:

$$
\begin{aligned}
\frac{H_{3}}{H_{0}}= & {\left[0.2854+0.2591\left(\frac{s}{S_{0}}\right)\right.} \\
& \left.+0.6171\left(\frac{s}{S_{0}}\right)^{2}-0.4837\left(\frac{s}{S_{0}}\right)^{3}\right]
\end{aligned}
$$

These selected empirical methods $\left(\mathrm{H}_{2}\right.$ and $\left.\mathrm{H}_{3}\right)$ can allow using constants obtained from sites different to where the model was evaluated, especially from neighboring stations with the same climatic properties. These relations were tested before for neighboring stations in literature and results were satisfactory. They have been tried previously and declared most accurate by many researchers in Turkey (Bakirci, 2009; Vecan, 2011; Ener Ruşen, 2013).

\section{4 HELIOSAT-1 method $\left(H_{4}\right)$}

The HELIOSAT method was first proposed by Cano et al. (1986), and later developed by Beyer et al. (1996). By counting pixels from satellite images taken from visible section channels, relative albedo $\rho$ is obtained. With these albedo values cloud index $n$ can be calculated:

$n=\frac{\rho-\rho_{\min }}{\rho_{\max }-\rho_{\min }}$

By using maximum (max) and minimum (min) pixel values of satellite images, relative albedo values $\rho_{\max }$ in cloudy conditions and $\rho_{\min }$ in clear sky conditions are found (Beyer et al., 1996; Hammer, 2000). The actual hourly solar radiation is obtained by clear sky index $k^{*}$ and clear sky radiation multiplication. $G_{\text {clear }}$ gives the hourly change of solar radiation in clear sky conditions (Beyer et al., 1996).

$G_{\text {hourly }}=k * G_{\text {clear }}$

Daily total clear sky radiation value $H_{4}$ is obtained from the sum of hourly radiation values. Detailed information on this topic can be found on studies conducted by many researchers (Hammer, 2000; Hammer et al., 2000; Ener Ruşen et al., 2013).

\subsection{Coupled method $\left(H_{5}\right)$ and average coupled method $\left(H_{6}\right)$}

In the coupled method, the basic principle is related to energy conservation. In order to obtain daily global solar radiation values, the overall effective reflection coefficient and the daily average of hourly cloud index are directly used. Ener Ruşen et al. (2013) obtained the following relation by using daily bright sunshine values from ground observations and daily cloud index values from satellite images:

$\frac{H_{5}}{H_{0}}=A_{0}+A_{1} \cdot n_{\text {avg }}+A_{2} \cdot \frac{s}{S_{0}}+A_{3} \cdot n_{\text {avg }} \cdot \frac{s}{S_{0}}$

where $n_{\text {avg }}$ is the average values of the daily cloud index; $s / S_{0}$ is the sunshine duration fraction, and $A_{0}, A_{1}, A_{2}$ and $A_{3}$ are defined as four dimensionless

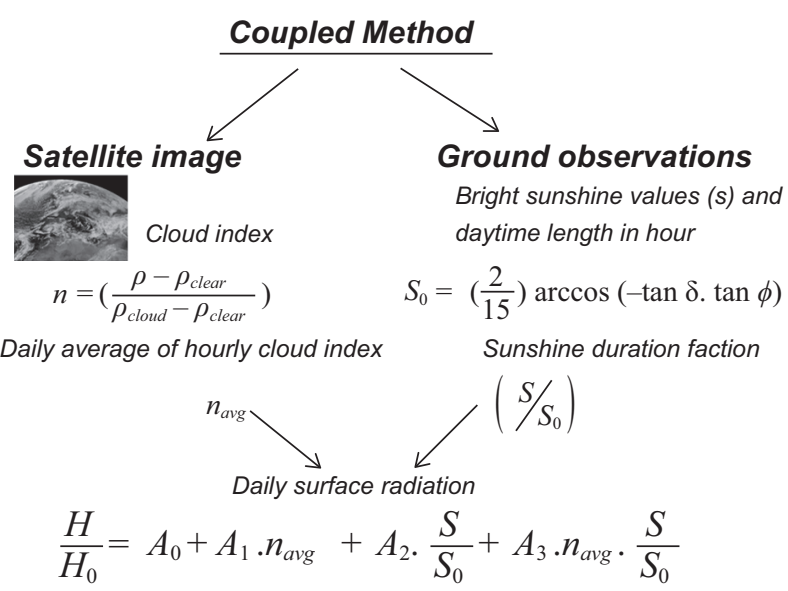

Fig. 2. Schematic representation of the coupled method's flow diagram. 
regression coefficients. The flow diagram in Figure 2 schematically illustrates the fundamental coupled method principle.

The equation for the coupled approach can be obtained in terms of four coefficients $\left(A_{0}, A_{1}, A_{2}\right.$, and $\left.A_{3}\right)$ that can be determined by multiple regression analysis. In the $H_{5}$ method, ground measurements of sunshine duration fraction $s / S$ and daily average values of cloud index $n_{\text {avg }}$ from satellite data were used to find these coefficients in a 1-yr period. As a result of multiple regression analyses of these data, different coefficients have been determined for each year for Nevşehir.

In order to obtain a distinct average coupled method $\left(H_{6}\right)$ equation, multiple regressions of 6-yr data sets have been used for the selected location. By using multiple regression analysis for all data sets, average coefficients were obtained for all data periods. Accordingly, the average coupled method equation $\left(H_{6}\right)$ for Nevşehir can be written as Eq.(9):

$$
\begin{aligned}
\frac{H_{6}}{H_{0}}= & 0.2767+0.0048 n_{\text {avg }} \\
& +0.4849 \frac{s}{S_{0}}-0.0109 n_{\text {avg }} \frac{s}{S_{0}}
\end{aligned}
$$

Here, the regression coefficients $A_{0}=0.2767$, $A_{1}=0.0048, A_{2}=0.4849$ and $A_{3}=0.0109$ are found .

\section{Statistical errors}

The obtained results are compared with the measured ground data by using two kinds of statistical error measures, RMBE and RRMSE. These measures used the daily difference between measured global solar radiation and values obtained with the different methods $\left(\omega_{e}-H_{i c}-H_{i m}\right)$. The RMBE and RRMSE values are defined by the following equations:

$$
\begin{aligned}
& r M B E=\left[\left(\sum_{1}^{d}\left(H_{i c}-H_{i m}\right)\right) / d\right] / H_{m} \\
& r R M S E=\left[\left\{\left(\sum_{1}^{d}\left(H_{i c}-H_{i m}\right)^{2}\right) / d\right\}^{1 / 2}\right] / H_{m}
\end{aligned}
$$

where $d$ is the data number, $H_{i c}$ is the value estimated with the method, $H_{i m}$ is the value of measured ground data and $H_{m}$ shows the daily average value of ground data (E1 Mghouchi et al., 2016). The found RRMSE value gives information about the quality of the solar radiation estimations obtained from the method. Here another error analysis procedure is the cumulative frequency in percentages. This analysis yields the cumulative distribution of the difference between the measured and calculated $H$ values and its absolute value.

\section{Results and discussion}

The performance of solar radiation estimation with the different methods analyzed was compared with the RRMSE and RMBE statistical error measures. In the applied methods, the daily global solar radiation and the daily bright sunshine data arrays from Nevşehir station were used. In addition, a 6-yr time period was chosen for this study, and daily values were simply obtained by collecting hourly values. Figure 3 shows representative results for relative values of the yearly mean bias error RMBE and yearly RRMSE for the selected location. As seen from Figure 3, in the

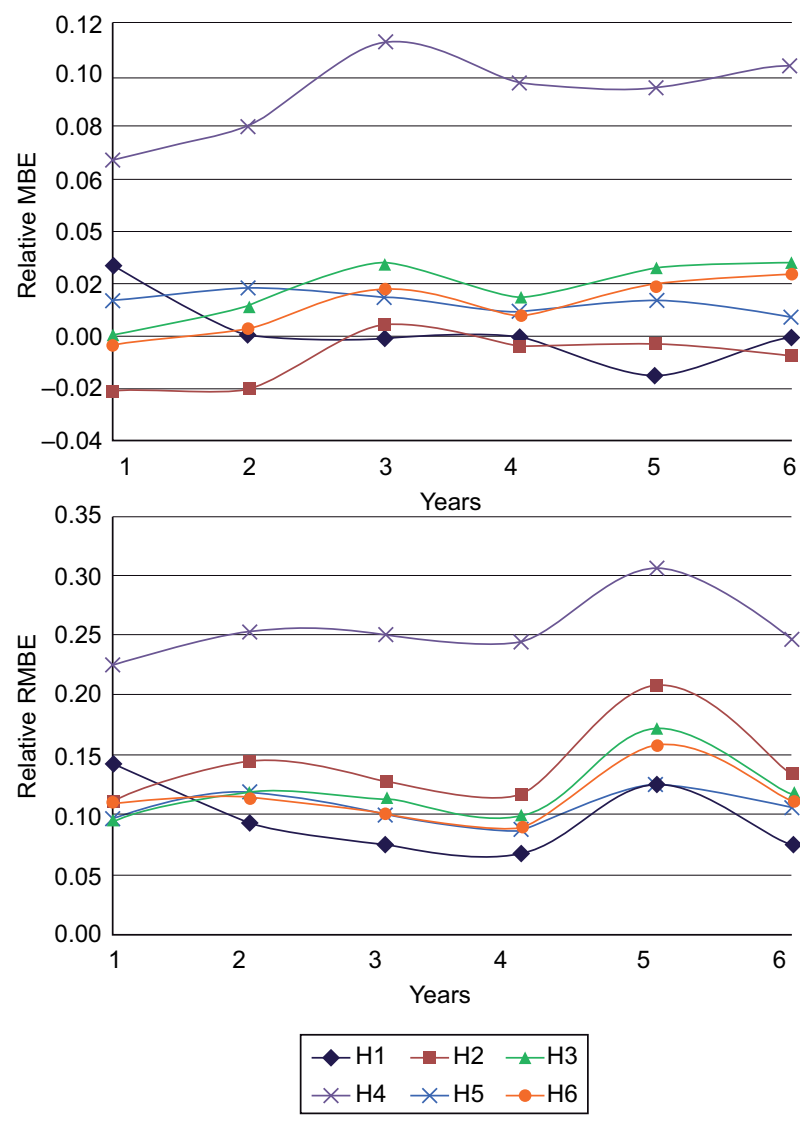

Fig. 3. RMBE and RRMSE values (statistical errors) for the selected 6-yr period, and for the six methods applied. 
HELIOSAT method $\left(H_{4}\right)$ the relative difference between measured and estimated values is higher at Nevşehir station during the whole year. Also, RRMSE error values are generally higher for this satellite method. However, the results of the RMBE and RMSE are the smallest values for the Angstrom method $\left(H_{1}\right)$ during the whole period of the study. Nevertheless, the coupled method $\left(H_{5}\right)$ and the average coupled method $\left(H_{6}\right)$ are better than the other methods $\left(\mathrm{H}_{2}, \mathrm{H}_{3}, \mathrm{H}_{4}\right)$, as expected. The best performing method after the Angstrom method $\left(H_{1}\right)$ is the coupled approach $\left(\mathrm{H}_{5}\right)$ method. Figure 3 shows that the coupled and average coupled approaches $\left(H_{5}\right.$ and $H_{6}$, respectively) yield quite satisfactory results when compared to the classical Angstrom method $\left(H_{1}\right)$.

In the fifth year all the methods show an increase in the RMSE error (Fig. 3). This is due to the weather conditions during this year, which were clammier and more overcast than in the other years. Both the overcast weather and cloud index increase along with the increment of the diffuse radiation parameter over different external atmospheric conditions. All estimation methods of global solar radiation are also affected by the diffuse radiation. Although the results show that RMSE error values of the fifth year are almost the same than in others years, it is worth mentioning that error values would become more changeable due to the weather conditions.

The cumulative frequency distribution curves for differences and absolute differences between estimated and measured daily global solar radiation are given in Figure 4 for all years.

In Figure 4, the cumulative frequency of the coupled method $\left(\mathrm{H}_{5}\right)$ and the averaged coupled method $\left(H_{6}\right)$ have about the same range of daily difference values $(91 \%)$ as can be monitored from panel (a). This value is slightly lower than the one obtained with the Angstrom method $\left(H_{1}\right)$, which gives a very good performance. The daily absolute difference values of these coupled methods are lower than $2.5 \mathrm{MJ} \mathrm{m}^{-2} \mathrm{day}^{-1}$. From the cumulative frequency graphs it can be seen that the estimation performance of the HELIOSAT method $\left(H_{4}\right)$ is poor. The daily difference values are about $50 \%$ and daily absolute difference values are out of range. Figure $4 b$ shows that the performance of methods $\mathrm{H}_{3}$ and $\mathrm{H}_{2}$ is similar. However, this figure shows that $\mathrm{H}_{2}$ produces a slight overestimation compared to $\mathrm{H}_{3}$.
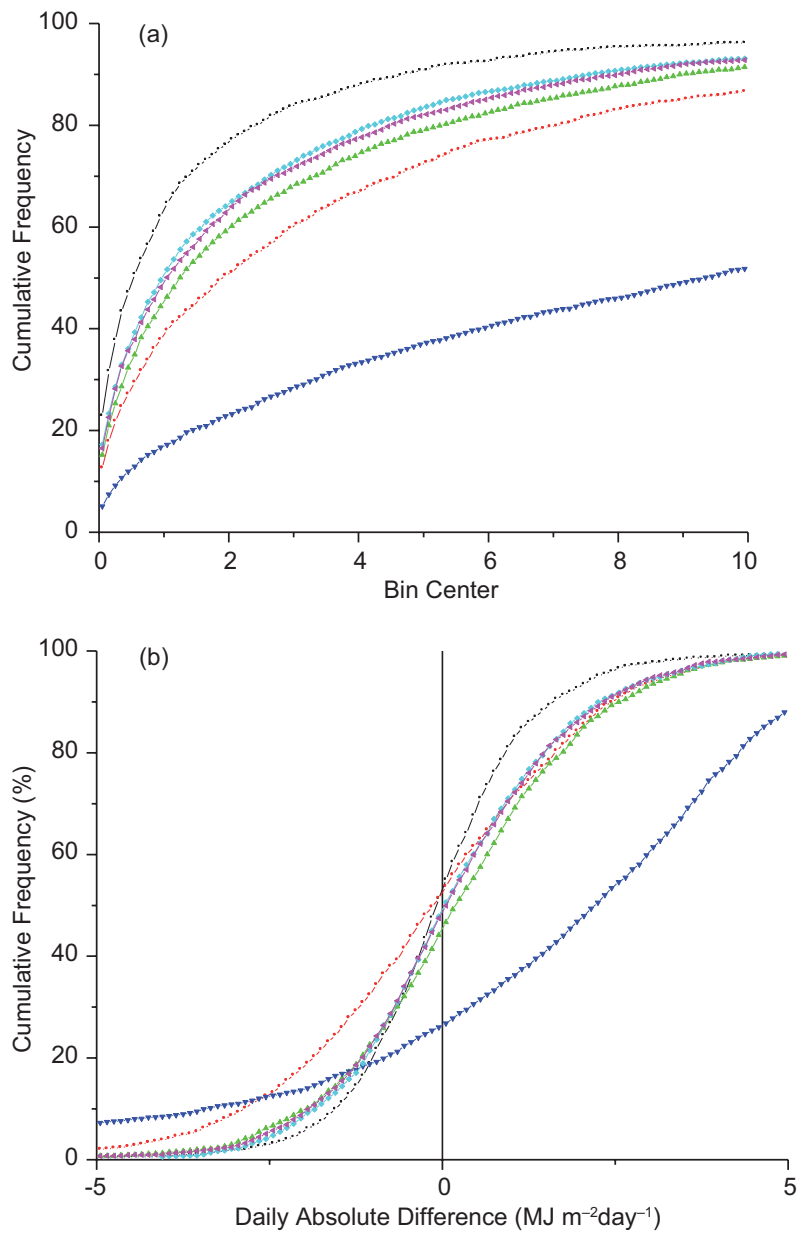

$-\cdot-H_{1}-\cdot-H_{2}-\triangle-H_{3}$
$-\cdot-H_{4}-H_{5}-\triangleleft-H_{6}$

Fig. 4. (a) Daily difference values of cumulative frequency and (b) daily absolute difference values of cumulative frequency for 6-yr data estimated with all methods for Nevşehir station.

The important result presented in this work is that the two applied models which use both sunshine duration data and cloud index information $\left(\mathrm{H}_{5}\right.$ and $H_{6}$ ) are more accurate than the direct application of the HELIOSAT model $\left(\mathrm{H}_{4}\right)$.

\section{Conclusions}

In this study, six methods were used to estimate the global solar radiation for a selected region (Nevşehir). These methods were three conventional empirical estimation methods $\left(H_{1}, H_{2}, H_{3}\right)$, the HELIOSAT 
method $\left(H_{4}\right)$ derived from satellite images, a coupled (hybrid) method $\left(H_{5}\right)$ and an average coupled method $\left(H_{6}\right)$. The selected conventional empirical methods have generally given successful results for Turkey. The obtained results were compared to 6-yr data from ground measurements. The quality of estimations is shown in Figure 3 by means of statistical relative error graphs; the results of cumulative frequency analyses are given in Figure 4. According to the results, it is acknowledged that data obtained from the coupled method using satellite imagery and surface observations are almost in the same reliability range than real data. In this study the coupled (hybrid) method was observed to perform better compared to empirical and satellite-based methods. The reliability of this estimation method should be investigated by using long-term data series and choosing stations with different climate types. This work and similar studies will provide useful information for climate research and for determining the future distribution of solar radiation.

\section{Acknowledgments}

I would like to thank the Turkish State Meteorological Service (TSMS) and Carl von Ossietzky University of Oldenburg for providing us with measured data. I would also like to thank Prof. Dr. Bülent Akınoglu and Dr. Annette Hammer for discussions and comments during the course of these studies. The author would like to express his gratitude to Karamanoglu Mehmetbey University for its support (Grant No. BAP-06-YL-18 and 06-M-2017).

\section{References}

Akinoglu B.G. and Ecevit A., 1990. Construction of a quadratic model using modified angstrom coefficients to estimate global solar radiation. Sol. Energy 45, 8592. DOI: 10.1016/0038-092X(90)90032-8

Aktag A. and Yilmaz E., 2012. A suitable model to estimate global solar radiation in Black Sea shoreline countries. Energ. Source Part A 34, 1628-36.

DOI: $10.1080 / 15567036.2011 .649339$

Alonso-Montesinos, J., Batlles F. J. and Bosch J. L., 2015. Beam, diffuse and global solar irradiance estimation with satellite imagery. Energ. Convers. Manage. 105, 1205-12. DOI: 10.1016/j.enconman.2015.08.037
Badescu V., Popović Z.V., Laurentiu F. and Bojić M., 2013. Preface to Special Issue: Renewable Energy in South-Eastern Europe. J. Renew. Sustain. Energ. 5, 41701. DOI: $10.1063 / 1.4818514$

Bakirci K., 2009. Correlations for estimation of daily global solar radiation with hours of bright sunshine in Turkey. Energy 34, 485-501.

DOI: $10.1016 /$ j.energy.2009.02.005

Beyer H.G., Costanzo C. and Heinemann D., 1996. Modifications of the Heliosat procedure for irradiance estimates from satellite images. Sol. Energy 56, 207-12. DOI: 10.1016/0038-092X(95)00092-6

Cano D., Monget J.M., Albuisson M., Guillard H., Regas N. and Wald L., 1986. A method for the determination of the global solar radiation from meteorological satellite data. Sol. Energy 37, 31-39.

DOI: $10.1016 / 0038-092 X(86) 90104-0$

Dagestad K.F., 2005. Estimating global radiation at ground level from satellite images. Ph.D. Thesis, University of Bergen, Norway.

Duffie J.A. and Beckman W.A., 1991. Solar engineering of thermal processing. 2nd ed. John Wiley and Sons, $936 \mathrm{pp}$.

El Mghouchi Y., El Bouardi A., Choulli Z. and Ajzoul T., 2016. Models for obtaining the daily direct, diffuse and global solar radiations. Renew. Sust. Energ. Rev. $56,87-99$.

DOI: $10.1016 /$ j.rser.2015.11.044

Ener Ruşen S., 2013. Linking satellite imagery to bright sunshine hours for the estimation of global solar irradiation. Ph.D. thesis, Middle East Technological Univeristy, Ankara, Turkey.

Ener Ruşen S., Hammer A. and Akinoglu B.G., 2013. Estimation of daily global solar irradiation by coupling ground measurements of bright sunshine hours to satellite imagery. Energy 58, 417-25.

DOI: $10.1016 /$ j.energy.2013.05.062

Ener Ruşen S., 2015. The performance evaluation of a new model based on bright sunshine hours and satellite imagery, for the estimation of daily global solar radiation for two locations in Turkey. Journal of Environmental Science 4, 1-9.

Ener Ruşen S., 2018. Modeling and analysis of global and diffuse solar irradiation components using the satellite estimation method of HELIOSAT. CMES-Comp. Model. Eng. 115, 327-43. DOI: 10.3970/cmes.2018.00159

Gana N.N. and Akpootu D.O., 2013. Angstrom type empirical correlation for estimating global solar radiation 
in north-eastern Nigeria. Journal of Engineering and Science 2, 58-78.

Hammer A., 2000. Anwendungspezifische solarstrahlungsinformationen aus meteosat-daten (Application of specific solar irradiance information from Meteosat data). Carl von Ossietzky University, Oldenburg.

Hammer A., Heinemann D., Lorenz E. and Lückehe B., 2000. Short-term forecasting of solar radiation: A statistical approach using satellite data. Sol. Energy 67, 139-50.

DOI: $10.1016 / \mathrm{S} 0038-092 \mathrm{X}(00) 00038-4$

Kandirmaz H.M., Kaba K. and Avci M., 2014. Estimation of monthly sunshine duration in Turkey using artificial neural networks. Int. J. Photoenergy, 2014, 1-9.

DOI: $10.1155 / 2014 / 680596$

Lu N., Qin J., Yang K. and Sun J., 2011. A simple and efficient algorithm to estimate daily global solar radiation from geostationary satellite data. Energy 36, 3179-88. DOI: 10.1016/j.energy.2011.03.007

Massen F., 2011. Sunshine duration from pyranometer readings. Luxembourg, $22 \mathrm{pp}$.

DOI: $10.13140 /$ RG.2.1.2255.7042

Muneer T., 2004. Solar radiation and daylight models. Elsevier, Amsterdam, New York, 392 pp.

Myers D.R., 2003. Solar radiation modeling and measurements for renewable energy applications : Data and model quality. In: International Expert Conference on Mathematical Modeling of Solar Radiation and Daylight Challenges for the 21st Century, Edinburgh, Scotland, pp. 1-15.
Pérez R., Seals R. and Zelenka A., 1997. Comparing satellite remote sensing and ground network measurements for the production of site/time specific irradiance data. Sol. Energy 60, 89-96. DOI: $10.1016 / \mathrm{S} 0038-092 \mathrm{X}(96) 00162-4$

Tasdemiroglu E. and Sever R., 1991. Estimation of monthly average, daily, horizontal diffuse radiation in Turkey. Energy 16, 787-90. DOI: 10.1016/0360-5442(91)90030-P

Teke A., Yıldırım H.B. and Çelik O., 2015. Evaluation and performance comparison of different models for the estimation of solar radiation. Renew. Sust. Energ. Rev. 50, 1097-1107. DOI: 10.1016/j.rser.2015.05.049

Threwartha G.T. and Lyle H.H., 1968. An introduction to climate. 5th ed. McGraw Hill, New York, 416 pp.

Ulgen K. and Hepbasli A., 2002. Estimation of solar radiation parameters for Izmir, Int. J, Ener. Res. 26, 807-823. DOI: $10.1002 /$ er.821

Ulgen K. and Hepbasli A., 2009. Diffuse solar radiation estimation models for Turkey's big cities. Energ. Convers. Manage. 50, 149-56.

DOI: $10.1016 /$ j.enconman.2008.08.013.

Vecan D., 2011. Measurement and comparison of solar radiation estimation models for Izmir, Turkey. M. Sc. Thesis, Izmir Institute of Technology, Turkey.

Yilmaz E., 2010. Zonal comparison in measured and predicted global solar radiation in Turkey and Chile. Energ. Source. Part A 32, 1454-59.

DOI: $10.1080 / 15567030902748615$ 